\title{
Intense atmospheric pollution modifies weather: a case of mixed biomass burning with fossil fuel combustion pollution in eastern China
}

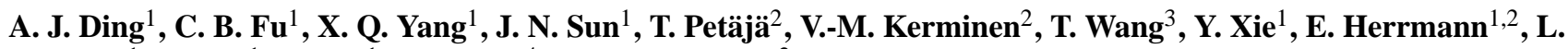 \\ F. Zheng ${ }^{1}$, W. Nie ${ }^{1}$, Q. Liu ${ }^{1}$, X. L. Wei ${ }^{4}$, and M. Kulmala ${ }^{2}$ \\ ${ }^{1}$ Institute for Climate and Global Change Research \& School of Atmospheric Sciences, Nanjing University, \\ Nanjing, 210093, China \\ ${ }^{2}$ Department of Physics, University of Helsinki, 00014 Helsinki, Finland \\ ${ }^{3}$ Department of Civil and Environmental Engineering, The Hong Kong Polytechnic University, Hong Kong, China \\ ${ }^{4}$ Shenzhen Meteorological Bureau, Shenzhen, China
}

Correspondence to: C. B. Fu (fcb@nju.edu.cn) and M. Kulmala (kulmala@cc.helsinki.fi)

Received: 30 April 2013 - Published in Atmos. Chem. Phys. Discuss.: 3 June 2013

Revised: 18 September 2013 - Accepted: 2 October 2013 - Published: 31 October 2013

\begin{abstract}
The influence of air pollutants, especially aerosols, on regional and global climate has been widely investigated, but only a very limited number of studies report their impacts on everyday weather. In this work, we present for the first time direct (observational) evidence of a clear effect of how a mixed atmospheric pollution changes the weather with a substantial modification in the air temperature and rainfall. By using comprehensive measurements in Nanjing, China, we found that mixed agricultural burning plumes with fossil fuel combustion pollution resulted in a decrease in the solar radiation intensity by more than $70 \%$, a decrease in the sensible heat by more than $85 \%$, a temperature drop by almost $10 \mathrm{~K}$, and a change in rainfall during both daytime and nighttime. Our results show clear air pollution-weather interactions, and quantify how air pollution affects weather via air pollution-boundary layer dynamics and aerosol-radiationcloud feedbacks. This study highlights cross-disciplinary needs to investigate the environmental, weather and climate impacts of the mixed biomass burning and fossil fuel combustion sources in East China.
\end{abstract}

\section{Introduction}

Air pollution and weather forecast are traditionally considered as two separate topics of interest in the field of atmospheric science. Synoptic weather is known to be an important factor driving air pollution episodes through processes like turbulent mixing, long-range transport, photochemical production and deposition (e.g., Hegarty et al., 2007; Ding et al., 2009; Y. Zhang et al., 2013). Many efforts have been put into developing methods of air quality prediction based on numerical weather forecasts (Jacobson, 2001a; Otte et al., 2005; Byun and Schere, 2006). However, only very few attempts were performed to investigate the weather-air pollution relations on the other way round, i.e., to understand the effects of air pollution on synoptic weather (e.g., Grell et al., 2005, 2011).

Due to rapid industrialization and vast consumption of fossil fuel (FF), China has been suffering from poor air quality for decades (He et al., 2002; Richter et al., 2005; Ding et al., 2008; Tie and Cao, 2009). The eastern and northern China plain, which contains more than half of the population of China and $10 \%$ of the world, is characterized with intense atmospheric pollution due to high amounts of FF combustion (Richter et al., 2005; Chan and Yao, 2008; Tie and Cao, 2009). During the last few years, many studies were conducted with a focus on air quality monitoring and understanding reasons and consequences of air pollution 
from these anthropogenic pollutants (e.g., Zhang et al., 2003; M. Zhang et al., 2013; Xu et al., 2008; Ding et al., 2013). Meanwhile, this area is one of the most important agricultural bases in China, and the agricultural activities, like intensive seasonally burning activities of agricultural straw, could cause mixed air pollution in this region (e.g., Wang et al., 2004; Yuan et al., 2010; Zhang et al., 2011; Ding et al., 2013). Many studies have shown that biomass burning (BB) smoke can change synoptic weather significantly (Robock, 1991; Andreae et al., 2004; Feingold et al., 2005; Grell et al., 2011), and that the mixed aerosols from BB and FF pollution play unique roles on changing regional even global climate (e.g., Jacobson, 2001b; Ramanathan et al., 2007). However, to the best of our knowledge, studies of air pollution-meteorology interactions in China mainly focused on FF pollutants (e.g., Zhang et al., 2007; Gong et al., 2007; Qian et al., 2009; Fan et al., 2012), and there is a lack of direct observation evidence showing the impact from either FF or BB pollution on everyday weather.

In this study, we report an outstanding case observed in western Yangtze River delta (YRD) of East China during the intensive BB period in June 2012. Based on comprehensive field measurement data, we explore the important connections between the mixed air pollution and synoptic weather in this region by showing a significant weather modification and failure in the prediction of air temperature and rainfall by the state-of-the-art numerical models during a heavy episode of extremely high concentration of particulate matter due to agricultural burning and FF combustion. We briefly introduce the experiment, data and modeling methodology in Sect. 2, and perform detailed analysis and discussions in Sect. 3. A summary and discussion on the implications are given in Sect. 4.

\section{Experiment, data and modeling}

\subsection{Field experiment}

We performed an intensive field measurement of trace gases, aerosols, fluxes and meteorological parameters in Nanjing during May-June 2012 to characterize the impact of BB activities on the environment in the western YRD of East China. Aerosols and trace gases $\left(\mathrm{O}_{3}, \mathrm{CO}, \mathrm{SO}_{2}, \mathrm{NO}, \mathrm{NO}_{\mathrm{x}}\right.$ and $\mathrm{NO}_{\mathrm{y}}$ ) were measured at the Xianlin "flagship" central site of the Stations for Observing Regional Processes of the Earth System (SORPES) (Ding et al., 2013), which is located on the top a hill (about $40 \mathrm{~m}$ a.g.l.) $20 \mathrm{~km}$ east of suburban Nanjing $\left(118^{\circ} 57^{\prime} 10^{\prime \prime}\right.$ E, $\left.32^{\circ} 07^{\prime} 14^{\prime \prime} N\right)$. Ding et al. (2013) gave detailed information on trace gases and $\mathrm{PM}_{2.5}$ mass measurements, which have been continuously conducted at the site since July 2011. Besides these parameters, scattering and backscattering coefficients were measured with a nephelometer (Aurora 3000). Water-soluble ions of $\mathrm{PM}_{2.5}$ were measured on-line with a time resolution of $1 \mathrm{~h}$ using Moni- tor for Aerosols and Gases in Air (MARGA, Metrohm Co.) (e.g., Du et al., 2010). Sub-micron particle sizing (6-800 nm) was measured using the differential mobility particle sizer (DMPS) (Aalto et al., 2001; Herrmann et al., 2013). Solar radiation and sensible heat flux were measured at an urban "satellite" flux site $15 \mathrm{~km}$ southwest of the Xianlin site, and details about the instruments were given by Liu et al. (2009).

\subsection{Meteorological modeling and weather forecast products}

To investigate the possible modification of weather during the pollution episode, we conducted numerical weather simulations using the Weather Research Forecasting (WRF) model. We employed the WRF version 3.3.1 with the Advanced Research WRF (ARW) dynamics solver (Skamarock et al., 2005), to conduct $24 \mathrm{~h}$ mesoscale meteorological simulation for each day during the study period. In this work, the WRF-ARW model was run in three two-way nested domains, with a horizontal grid size of 45,15 and $5 \mathrm{~km}$, covering East Asia, East China and the YRD region, respectively. All domains have 37 terrain-following vertical sigma levels. A Mellor-Yamada-Janjic turbulence kinetic energy scheme was used for planetary boundary layer (PBL) closure, and a Kain-Fritsch (new Eta) scheme was chosen for cumulus parameterization for all the domains except the finest one. A similar model configuration has been applied in our previous studies (e.g., Ding et al., 2009).

We used the NCEP Final Operational Global Analysis (FNL) data on $1.0^{\circ} \times 1.0^{\circ}$ grids and 26 vertical pressure levels, prepared operationally every $6 \mathrm{~h}$, to provide the boundary and initial conditions for the WRF simulations. This product is from the Global Data Assimilation System (GDAS), which continuously collects observational data from the Global Telecommunications System (GTS), and other sources, for many analyses. The original data are available from the Research Data Archive (RDA) (http://rda.ucar.edu) in data set number ds083.2. We also used $12 \mathrm{~h}$ air temperature forecasts data provided by the European Centre for Medium-Range Weather Forecasts (ECMWF). The data were operationally made by ECMWF atmospheric forecast model. The products have a horizontal resolution of $0.125^{\circ} \times 0.125^{\circ}$ and a temporal resolution of $6 \mathrm{~h}$. Besides these simulation results, we also referenced the daily weather forecasts report made by the Chinese Meteorological Agency and Jiangsu Provincial Meteorological Bureau. These forecasts were generally made based on ensemble numerical modeling products and referencing of global modeling products from ECMWF and Japan Meteorological Agency, etc. 


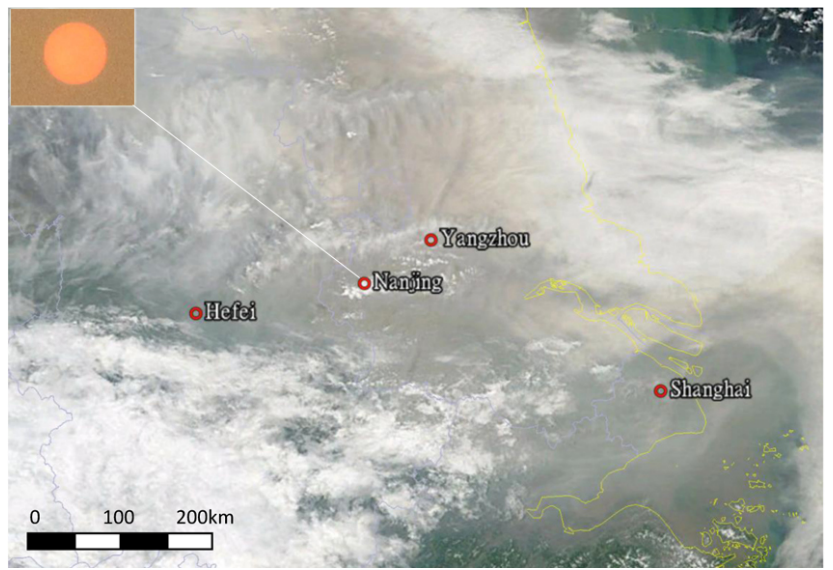

Fig. 1. A Terra satellite true color image of East China on 10 June, 2012. Note: the satellite images were provided by MODIS Rapid Response Subsets of NASA. The top left corner gives a photo of the sun seen from the ground at 10:30 LT of 10 June 2012 in Nanjing.

\section{Results and discussions}

\subsection{Chemical measurements}

During 9-11 June 2012, a thick yellow haze blanketed Nanjing and adjacent cities in the west Yangtze River delta region. Satellite images showed a brown and a foggy belt over Nanjing, Yangzhou and the north regions (see Fig. 1). Many cities were in heavy haze with very low visibility. MODIS active fire data clearly showed that the intensive burning activities occurred in the north of Anhui Province on 9 June 2012 (Fig. 2). Ding et al. (2013) briefly discussed weather and air mass transport characteristics for this case, and clearly showed the agriculture burning plumes transported from the north to Nanjing and adjacent areas on 10 June 2012.

We observed extremely high PM mass and number concentrations together with high concentrations of trace gases like $\mathrm{CO}, \mathrm{NO}_{\mathrm{y}}$, and $\mathrm{SO}_{2}$ from late afternoon of 9 June to the morning of 11 June (Fig. 3). In late afternoon of 9 June, 2012, the $\mathrm{PM}_{2.5}$ concentration experienced a sharp increase with a 5 min maximum up to $468 \mu \mathrm{g} \mathrm{m}^{-3}$ at 20:00 LT, followed by the high concentration of $\mathrm{PM}_{2.5}$ mass with an average value in excess of $200 \mu \mathrm{g} \mathrm{m}^{-3}$ that lasted for about $36 \mathrm{~h}$. The total mass concentration of $\mathrm{PM}_{2.5}$, together with the water-soluble ions, also shows that carbonaceous matter contributed a large fraction (about $50 \%$ ) of the mass during the pollution event. A measurement of aerosol number size distribution during the event shows high aerosol number concentrations, particularly in the nucleation mode sizes at $10-25 \mathrm{~nm}$ and in accumulation mode sizes at $100-200 \mathrm{~nm}$, indicating emissions of both ultrafine particles and larger particles (Fig. 4). The concurrent measurement of aerosol optical properties shows that the "dry" aerosol scattering coefficients reached up to $5000 \mathrm{Mm}^{-1}$ during the pollution event (Fig. 3b). The real aerosol scattering was even more pronounced considering the

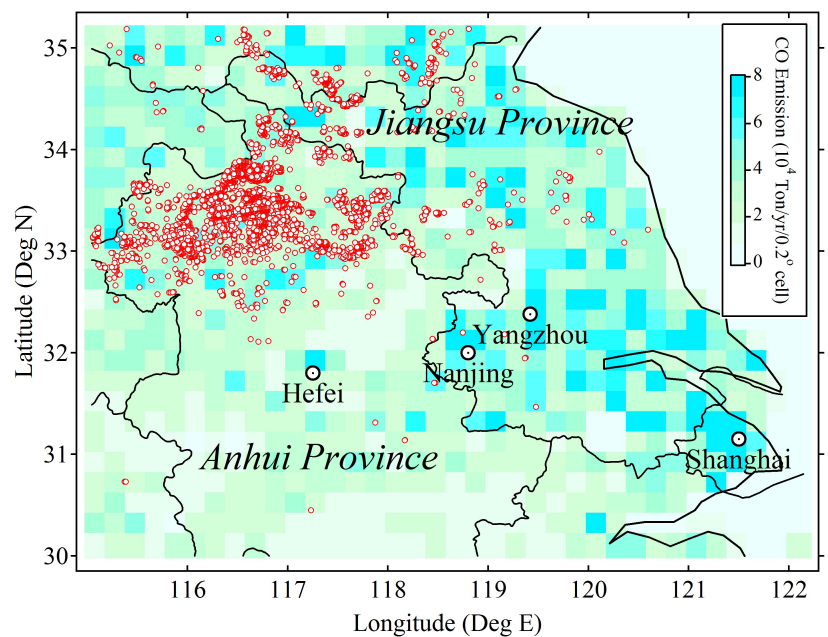

Fig. 2. A map showing emission inventory of carbon monoxide and fire events on 9 June 2012 in the study region. Note: CO emission inventory was provided by Q. Zhang at Tsinghua University (Zhang et al., 2009). The fire data are from MODIS Collection 5 Active Fire Product provided by University of Maryland (Giglio et al., 2006).

hygroscopic growth of aerosol particles under conditions of high relative humidity (Kulmala et al., 2001; Malm and Day, 2001; Liu et al., 2011).

The time series of water-soluble ions of $\mathrm{PM}_{2.5}$ given in Fig. $3 \mathrm{~b}$ also indicated a high concentration of sulfate $\left(\mathrm{SO}_{4}^{2-}\right)$, with an average value of about $40 \mu \mathrm{g} \mathrm{m}^{-3}$ during the pollution episode. Previous studies have reported a high proportion of sulfate in $\mathrm{PM}_{2.5}(20-30 \%)$ in the eastern China region because of the high consumption of coal (Zhou et al., 2009; M. Zhang et al., 2013). Our measurements also revealed a high proportion of sulfate $(\sim 30 \%)$ in the preepisode period, but a significant drop in this proportion during the event, showing an anti-correlation with the $\mathrm{KCl}$ percentage (Fig. 3c). However, in the afternoon of 10 June, the particulate sulfate fraction showed a remarkable increase, together with a plume of gas-phase $\mathrm{SO}_{2}$ and particulate sulfate with a maximum of $23.5 \mathrm{ppbv}$ and $69.9 \mathrm{\mu g} \mathrm{m}^{-3}$, respectively. As biomass burning has smaller emission factors of $\mathrm{SO}_{2}$ and sulfate compared with FF combustion, these results suggest a mixture of pollution from FF combustion and BB plumes. A high percentage of $\mathrm{KCl}$ (about $10 \%$ ) and carbonaceous matter (about $50 \%$ ) of the mass during the event confirmed that Nanjing had been influenced by young BB smoke (Li et al., 2003). Here the observed high sulfate associated with $\mathrm{SO}_{2}$ in the afternoon of 10 June was also probably due to complex chemical reactions. For example, studies suggest that in young smoke plumes heterogeneous chemistry of $\mathrm{SO}_{2}$ might contribute to a fast formation of sulfate (e.g., Alvarado and Prinn, 2009).

The scatterplots of $\mathrm{KCl}$, sulfate and $\mathrm{CO}$ vs. $\mathrm{PM}_{2.5}$ mass concentration for the episode and non-episode days given in Fig. 5 suggest a remarkable difference in the chemical 


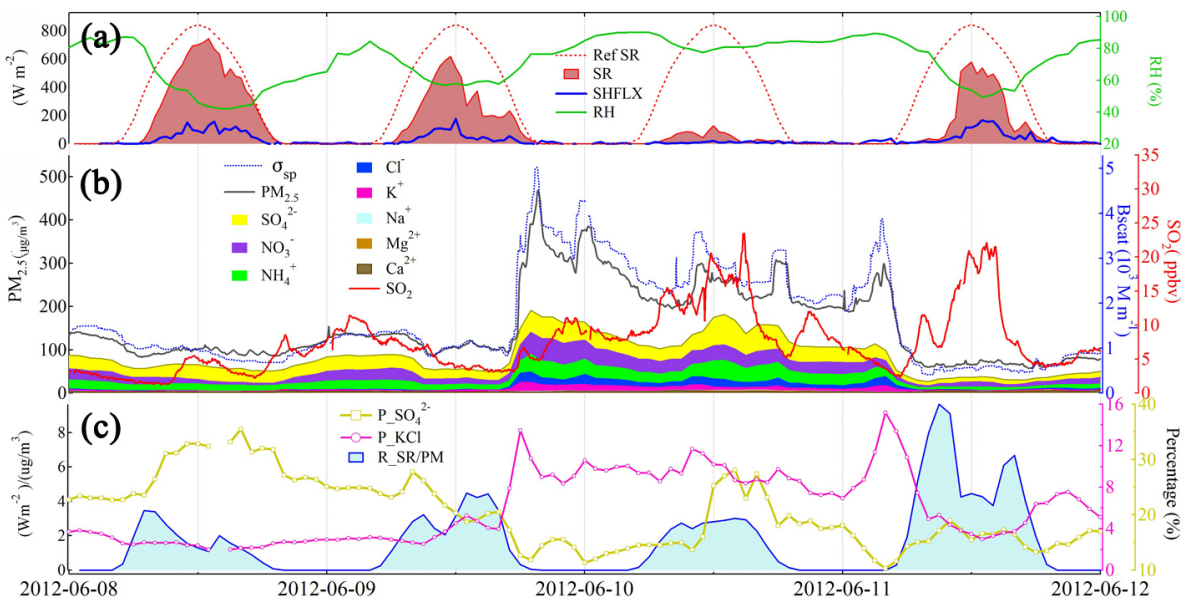

Fig. 3. (a) Solar radiation, sensible heat flux and relative humidity recorded at a urban flux site of SORPES. (b) PM 2.5 mass, water-soluble ions, aerosol scattering coefficient (at $650 \mathrm{~nm}$ ) and $\mathrm{SO}_{2}$ measured at the SORPES Xianlin site. (c) Proportions of sulfate and $\mathrm{KCl}$ in the total $\mathrm{PM}_{2.5}$ mass and the ratio of "blocked" solar radiation over the $\mathrm{PM}_{2.5}$ mass concentrations $\left(\mathrm{R} \_\mathrm{SR} / \mathrm{PM}=\left(\mathrm{Ref} \_\mathrm{SR}-\mathrm{SR}\right) / \mathrm{PM} 2.5\right)$ at the Xianlin Site. Note: a reference of clear-sky solar radiation (Ref_SR) was determined from the measured solar radiation in the afternoon of 13 June, when Nanjing was cloud-free and with relatively low $\mathrm{PM}_{2.5}\left(\sim 50 \mu \mathrm{g} \mathrm{m}^{-3}\right)$.
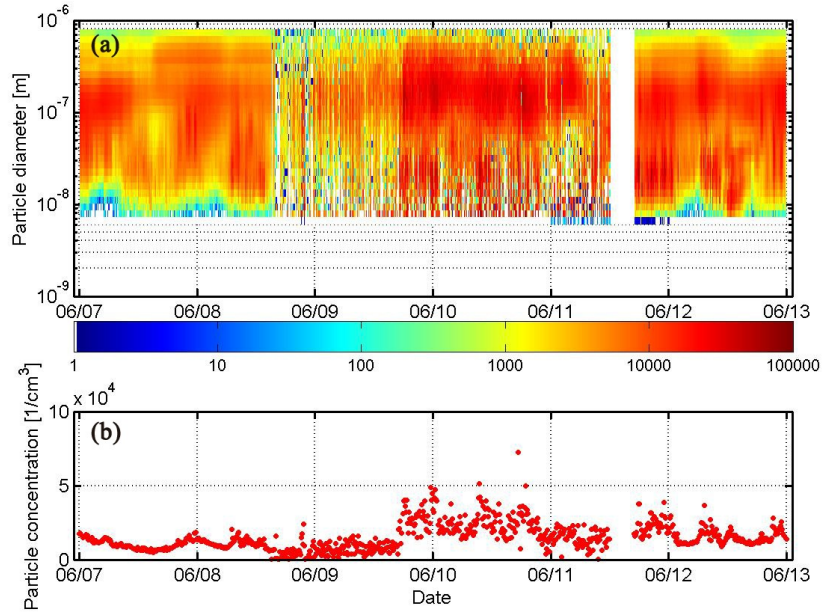

Fig. 4. (a) Aerosol size distribution measured with a differential mobility particle sizer (DMPS), (b) integrated total particle number concentrations in the sub-micron size measured at the SORPES Xianlin site.

composition of particulate matter during the episode and non-episode days. Higher $\mathrm{KCl} / \mathrm{PM}_{2.5}$ ratios and lower sulfate $/ \mathrm{PM}_{2.5}$ and $\mathrm{CO} / \mathrm{PM}_{2.5}$ ratios were evident during the episode days, suggesting different emission and chemical characteristics between the BB and FF combustion plumes. Examination of the black ellipses in Fig. 5a-c, corresponding to the data on the afternoon of 10 June, suggests that the observed air masses had a clear signal of BB plumes (see high $\mathrm{KCl} / \mathrm{PM}_{2.5}$ ratio in Fig. 5a) and also signals from FF combustion (see the marked data and the blue regression line of $\mathrm{SO}_{4}^{2-}$ and $\mathrm{CO}$ vs. $\mathrm{PM}_{2.5}$ in Fig. $5 \mathrm{~b}$ and c, respectively).
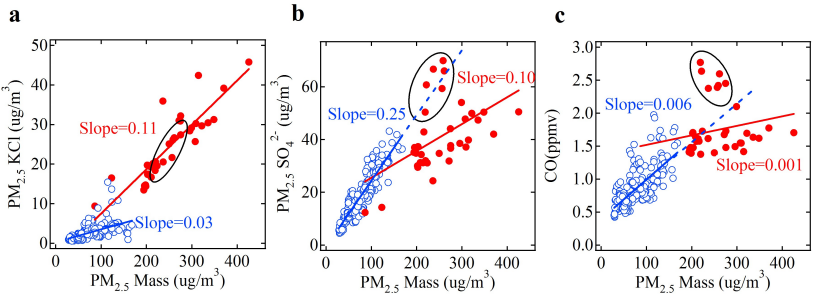

Fig. 5. Scatterplots of (a) $\mathrm{KCl}$, (b) sulfate and (c) $\mathrm{CO}$ vs. $\mathrm{PM}_{2.5}$ mass concentration separately for the pollution episode (red) and for the non-episode (blue) days between 7 and 15 June 2012. Note: black ellipses mark the data for a period of 12:00-17:00 LT, 10 June.

These results further confirm that the pollution on 10 June was caused by a mixture of particulate pollutants originating both from the FF burning and from the BB activities.

\subsection{Evidence of weather modification}

The high concentrations of scattering and absorbing aerosols could affect significantly the radiative transfer of solar radiation during the episode. Both measured solar radiation intensity and sensible heat flux showed very low values on 10 June (128.5 and $21.6 \mathrm{~W} \mathrm{~m}^{-2}$ in average) in comparison with nonepisode days (580.9 and $172.4 \mathrm{~W} \mathrm{~m}^{-2}$ on average, see Fig. 3a and Table 1). Interestingly, a weather forecast from the local meteorological agency suggested a daily maximum air temperature as high as $34^{\circ} \mathrm{C}$ and formation of thunderstorms in the afternoon of 10 June in Nanjing. However, the measured daily maximum air temperature rose only up to $26.5^{\circ} \mathrm{C}$, and no rainfall occurred in Nanjing and the surrounding cities during that afternoon. The difference between the forecast 
and the observations indicates a modification of weather by the air pollution.

In order to understand to what extent the air pollution changed the regional and local meteorological conditions, we compared the observed surface air temperature with WRF simulations and NCEP FNL data for the three cities, Nanjing, Yangzhou and Hefei, in the period of 8-11 June (Fig. 6a-c). The simulations and data showed a good agreement with observations for the three cities when the heavy air pollution was not present. However, a large difference in the air temperature occurred in Nanjing on 10 June, with a daily maximum anomaly as large as $7.1^{\circ} \mathrm{C}$. At Yangzhou the difference was $5.9^{\circ} \mathrm{C}$ and $9.2^{\circ} \mathrm{C}$ on 9 and 10 June, respectively. Even larger differences were detected between the FNL data and the observations. For Hefei city, which was not affected by the pollution event during the four days, only a small difference $\left(\sim 1.2^{\circ} \mathrm{C}\right.$ in average $)$ was found between the simulated and observed air temperature. It needs to be pointed out that the air pollution index (API) in Fig. 6a-c is a dailyaverage value, and a nighttime sharp plume could produce a high daily API. In addition, besides the pollutant concentrations also the PBL height is an important factor influencing the total optical depth of air pollution. For these reasons, the highest API at Yangzhou on 9 June was associated with a moderate modification of daytime air temperature.

Here our results suggest a much more substantial cooling $\left(5-10^{\circ} \mathrm{C}\right)$ associated with extreme pollution events than previously observed $\left(1-5^{\circ} \mathrm{C}\right)$ under the influence of forest fire smoke in remote areas like Amazon, Africa, Siberia and West United States (Wexler, 1950; Robock, 1991; Carmona et al., 2008). Since clouds also play an important role in the radiative transfer (Andreae et al., 2004; Li et al., 2011a, b; Wang et al., 2012), we calculated the ratio of "blocked" solar radiation over $\mathrm{PM}_{2.5}$ mass (R_SR/PM). Figure $3 \mathrm{c}$ shows a similar diurnal pattern of the ratio on 10 June with 8-9 June, but a different one on 11 June when the high peaks of this ratio were associated with thick clouds. These results suggest that the substantial drop in the solar radiation intensity was associated with atmospheric pollution rather than with clouds on 10 June. This could be confirmed with visual observations: the sun was seen in the sky on that day, but it looked orange in color during broad daylight in Nanjing (see the upper left corner of Fig. 1).

To understand the difference in vertical air temperature profiles further, we compared results from radiosonde measurements, WRF simulations, FNL data and ECMWF $12 \mathrm{~h}$ forecasts at Nanjing for 20:00 LT of 9-11 June (Fig. 6d). On the pre- and post-event days, the numerical models agreed quite well with the radiosonde data, but for 10 June a significant difference was apparent extending from the surface to the $950 \mathrm{hPa}$ level. Converting the temperature profile to the corresponding potential temperature profile revealed a stable boundary layer below $900 \mathrm{hPa}$, which corresponds approximately the lowermost $1 \mathrm{~km}$ of the PBL. This kind of an inverted potential temperature profile was very likely caused

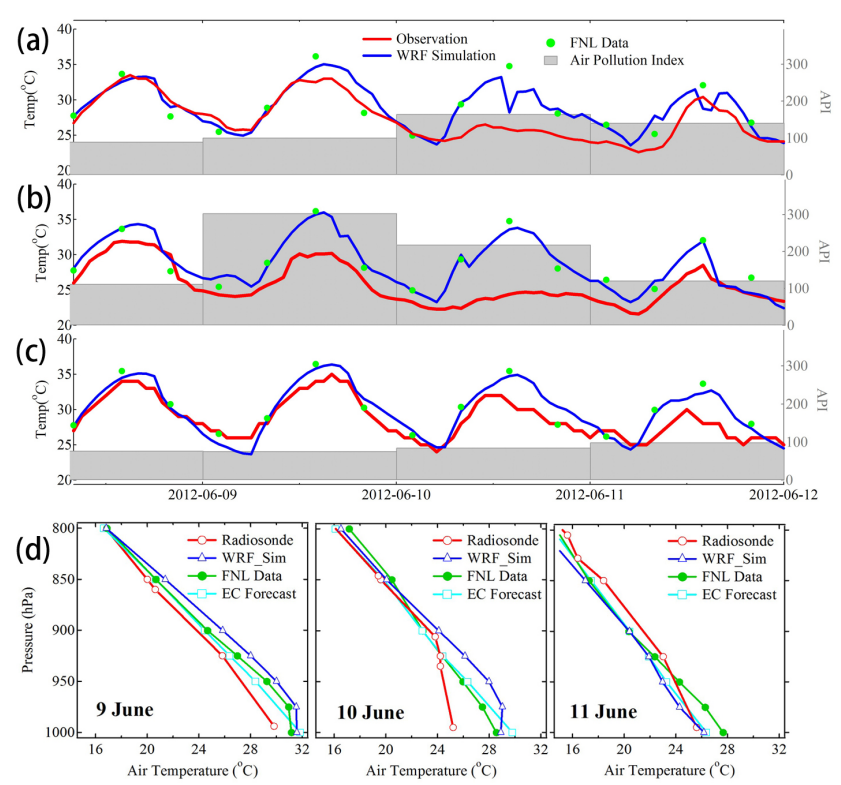

Fig. 6. A comparison of (a) $2 \mathrm{~m}$ air temperature from the WRF simulation, FNL and from the observations, and a daily mean air pollution index in Nanjing, (b) and (c) same as (a) but for Yangzhou and Hefei City, respectively, and (d) comparisons of air temperature vertical profiles from the WRF simulations, FNL data, ECMWF forecast products and radiosonde measurement over Nanjing at 20:00 LT for 9-11 June 2012.

by the heat absorbed by the suspended aerosols like black carbon in the upper PBL, whereas the lower PBL cooled down due to reduced amount of solar radiation reaching down to the surface. Previous studies have reported such kinds of effects in smoke plumes and suggested that the upper level heating together with a surface cooling could increase the PBL stability (Andreae et al., 2004; Feingold et al., 2005).

Besides the direct effects and associated feedbacks outlined above, there are indications that aerosols affected the precipitation pattern, especially convective precipitation. Figure 7 shows a comparison of WRF-simulated and observed $6 \mathrm{~h}$ rainfall over Jiangsu Province for the periods of afternoon of 10 June and early morning of 11 June 2012. For the afternoon of 10 June, it can be clearly seen that the WRF simulation suggested a convective rainfall to occur in Nanjing and the south region with a scale of about $100 \mathrm{~km}$, with the rainfall center passing by Nanjing around 14:00 LT, corresponding to the sharp drop of air temperature shown in Fig. 7a. The WRF simulations were consistent with the weather predictions by the local meteorological agency.

However, the observations did not show any rainfall on 10 June in Nanjing or the surrounding regions until during the early morning of 11 June when storms occurred in the north of Jiangsu Province with $13 \mathrm{~mm}$ rainfall over $6 \mathrm{~h}$, about $120 \mathrm{~km}$ away from Nanjing (see Table 2). The WRF simulation predicted convective rainfall there, but the predicted 
Table 1. Solar radiation, sensible heat flux and $\mathrm{PM}_{2.5}$ mass for episode and non-episode days.

\begin{tabular}{lll}
\hline Items & Episode day (10 June) & Pre- and post-episode days \\
\hline $\begin{array}{ll}\text { Maximum solar } \\
\text { radiation }\end{array}$ & $128.5 \mathrm{~W} \mathrm{~m}^{-2}(12: 00)$ & Average: $580.9 \mathrm{~W} \mathrm{~m}^{-2}$ \\
& & $\begin{array}{l}618.3 \mathrm{~W} \mathrm{~m}^{-2}(11: 30,9 \mathrm{June}) \\
578.9 \mathrm{~W} \mathrm{~m}^{-2}(12: 00,11 \mathrm{June})\end{array}$ \\
\hline Maximum & $21.6 \mathrm{~W} \mathrm{~m}^{-2}(12: 00)$ & Average: $172.4 \mathrm{~W} \mathrm{~m}^{-2}$ \\
sensible heat & & $177.0 \mathrm{~W} \mathrm{~m}^{-2}(12: 00,9 \mathrm{June})$ \\
flux & & $167.8 \mathrm{~W} \mathrm{~m}^{-2}(13: 00,11 \mathrm{June})$ \\
\hline $\mathrm{PM}_{2.5}$ mass & $261 \mu \mathrm{g} \mathrm{m}^{-3}(12: 00)$ & Average: $85 \mu \mathrm{g} \mathrm{m} \mathrm{m}^{-3}$ \\
& & $104 \mu \mathrm{g} \mathrm{m}^{-3}(11: 30,9 \mathrm{June})$ \\
& & $66 \mu \mathrm{g} \mathrm{m}^{-3}(12: 00,11 \mathrm{June})$ \\
\hline
\end{tabular}
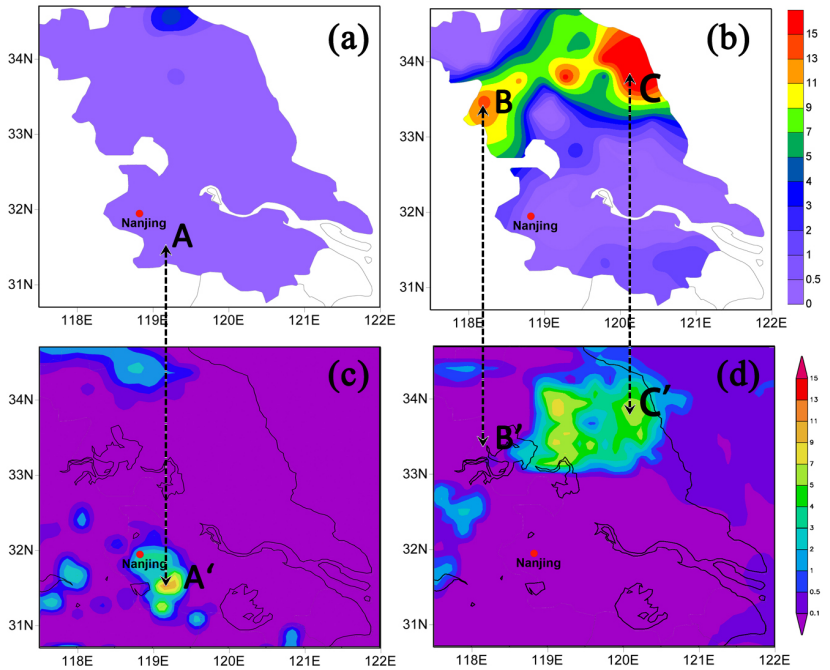

Fig. 7. A comparison of observed and WRF-simulated amounts of precipitation. (a, b) Observed $6 \mathrm{~h}$ total rainfall in Jiangsu Province for the period of 12:00-17:00 LT on 10 June and 00:00-05:00 LT on 11 June, 2012, respectively. (c, d) WRF-simulated $6 \mathrm{~h}$ total rainfall in the study region for the periods of 12:00-17:00 LT on 10 June and 00:00-05:00 LT on 11 June 2012, respectively. Note: unit of rainfall is $\mathrm{mm}$. The observed rainfall data were obtained from Jiangsu Automatic Meteorological Observation Network of Jiangsu Provincial meteorological Bureau. Points $\mathrm{A} / \mathrm{A}^{\prime}, \mathrm{B} / \mathrm{B}$ ' and $\mathrm{C} / \mathrm{C}^{\prime}$ are marked for the statistics in Table 2 .

pattern deviated from the observed one as the latter showed a stronger rainfall in the coastal region and an isolated precipitation center north of Nanjing (see Fig. 7b and Table 2). Previous studies in Amazon suggest that biomass-burning plumes can cause a decrease or an increase of cloudiness depending on the height of plumes (Feingold et al., 2005). Research also suggests that a suppression of low-level aerosol rainout/washout may cause intense thunderstorms and large hail (Andreae et al., 2004; Rosenfeld et al., 2008). In this case, the pollution seems to have both features depending on the time of the day and location.
Table 2. Observed and WRF-simulated rainfall at points A/A', B/B' and $\mathrm{C} / \mathrm{C}^{\prime}$ in Fig. 7.

\begin{tabular}{lll}
\hline Items & $\begin{array}{l}\text { WRF- } \\
\text { simulated } \\
\text { rainfall (mm) }\end{array}$ & $\begin{array}{l}\text { Observed } \\
\text { rainfall (mm) }\end{array}$ \\
\hline $\begin{array}{l}\text { Point A/A' } \\
(12: 00-17: 00, \text { June) }\end{array}$ & 12.0 & 0.0 \\
\hline $\begin{array}{l}\text { Point B/B' } \\
\text { (00:00-05:00, 11 June) }\end{array}$ & 0.0 & 13.5 \\
\hline $\begin{array}{l}\text { Point C/C' } \\
(00: 00-05: 00,11 \text { June) }\end{array}$ & 6.2 & 22.0 \\
\hline
\end{tabular}

The exact reasons for the modification of rainfall need some more advanced modeling work based on on-line coupled models (e.g., WRF-Chem) (Grell et al., 2005, 2011). However, because of the lack of measurements of the spatial and vertical distributions of aerosol concentrations and their optical properties, it is a huge challenge to quantify the mechanisms and processes influencing the rainfall modification in this case. Instead, we carried out a sensitivity test using the observation nudging function of WRF FourDimensional Data Assimilation (FDDA) (Liu et al., 2005) to identify whether the PBL dynamics influenced the daytime rainfall around Nanjing. By using the $2 \mathrm{~m}$ air temperature at Nanjing nudged (with a default nudging coefficient as 3E-4) during the simulation, the model produced an area $\left(\sim 25000 \mathrm{~km}^{2}\right)$ of lower air temperatures $\left(5^{\circ} \mathrm{C}\right.$ lower than the surrounding area) around Nanjing (see Fig. 8a). Under such conditions, the daytime rainfall around Nanjing completely disappeared (Fig. 8b). These results give further evidence that the increased daytime PBL stability and the reduced convection were the dominate causes for the burning of the mesoscale convection system in that afternoon. 


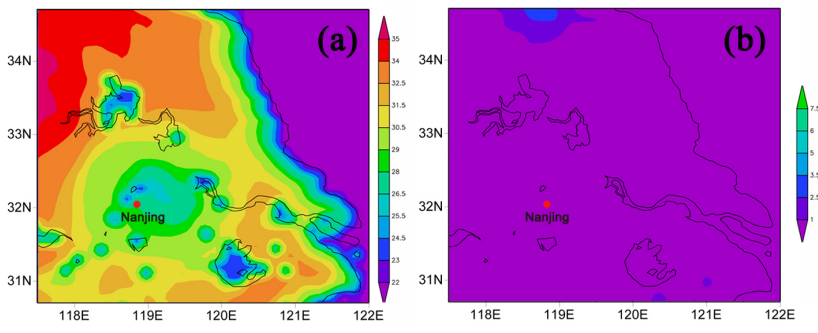

Fig. 8. Simulated (a) $2 \mathrm{~m}$ air temperature at 14:00 LT, 10 June and (b) $6 \mathrm{~h}$ total rainfall for the period of 12:00-17:00 LT on 10 June using WRF-FDDA observation nudging with $2 \mathrm{~m}$ air temperature at Nanjing.

\section{Summary and implications}

Here we have shown how significantly the intense air pollution modifies the local synoptic weather by influencing solar radiation, sensible heat flux, air temperature and precipitation. This leads to a crucial failure of daily weather forecast under the condition of mixed agriculture burning plumes and FF combustion pollutants. The above findings from this case are suggestive of strong feedback between a heavy aerosol loading, radiative transfer, air temperature profile/stability and precipitation. We summarize the main processes and their interactions in a schematic picture (Fig. 9). Here the enhanced PBL stability initiated by the pollution suppresses the vertical mixing and dispersion of the pollutants, resulting in more intense pollution in the lower PBL. The cooling of the PBL and resulting increase in the relative humidity amplify the feedback further by increasing the aerosol scattering coefficient through hydroscopic effects (Malm and Day, 2001; Liu et al., 2011). The changed PBL stability and the mixed aerosols further modify cloud properties and precipitation patterns. For the daytime modification of a storm, the dynamic effects resulting from the increased PBL stability and less convection seem to be the dominate factors. These feedbacks between air pollution-boundary layer dynamics and aerosol-radiation-cloud interactions suggest important implications in the following aspects.

Firstly, from a weather forecast point of view, this case clearly demonstrates that heavy and complex air pollution could modify weather in a substantial way in China. Although on-line coupled models have recently been developed and improved, and may have the capability to address some of these interactions and feedbacks (Giorgi et al., 2003; Grell et al., 2005, 2011), their performance has not been sufficiently evaluated in heavily polluted areas like East Asia. The real-time changed emissions like man-made agricultural fires also challenge the capability of numerical weather forecast.

Secondly, for the aspect of air pollution control measures, the mechanisms shown in Fig. 9 suggests that changes in the PBL stability caused by upwind regional plumes may further enhance the accumulation of local anthropogenic pollu-

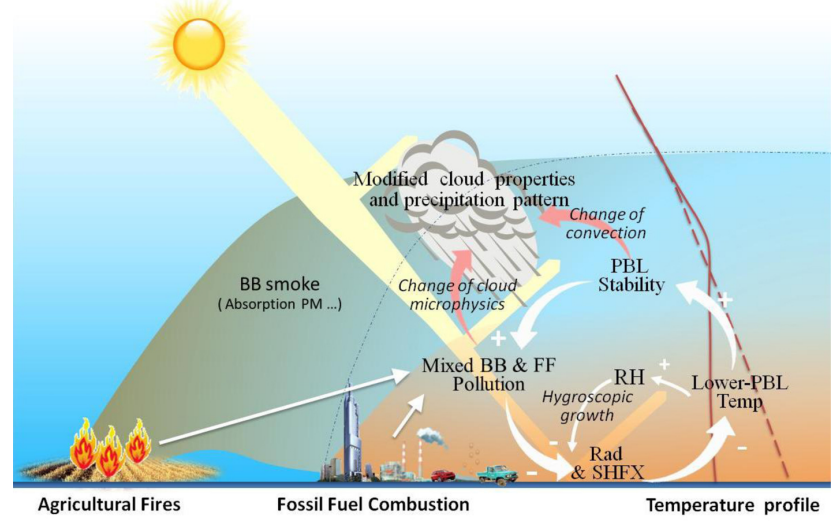

Fig. 9. A schematic figure for interactions of air pollution-PBL dynamics and aerosol-radiation-cloud interaction under a condition of mixed agriculture burning plumes and fossil fuel combustion pollutants. Note: yellow bands show the radiative transfer of solar radiation. The brown solid and dashed lines mean the air temperature profiles for episode and non-episode cases, respectively. The black thin dashed line represents the top of fossil fuel combustion plume under a non-episode condition. The plus $(+)$ and minus $(-)$ signs mean enhancement and reduction of a target process, respectively.

tants in lower PBL and cause extreme air pollution around the surface. Currently, complaints are often being heard that off-line air quality forecast models sometimes significantly underestimate the extremely high pollution concentrations in megacities in the eastern and northern China. One of the main reasons for this could be PBL-air pollution interactions not included in the offline forecast models. Therefore, for North and East China a fully coupled meteorology-air quality model will be needed because this region faces frequent heavy aerosol pollution and also a complex multi-scale distribution of pollutant emission (i.e., from single city, city clusters to regional scales, mixed $\mathrm{BB} / \mathrm{FF}$ sources).

Finally, even though this study is an extreme case observed until recently with advanced measurement techniques, statistics of $11 \mathrm{yr}$ (2002-2012) MODIS active fire data suggests that there is a well-defined BB band located from central to eastern China, which overlaps with the high rate of FF combustion emission (Fig. 10). The seasonal variation of the fires suggests that in June (mainly in the first two weeks of June), the fire data have a portion of up to $70 \%$ of the entire year on average. Because early and middle June is the pre-plum rains $(M e i-y u)$ period $(\mathrm{Fu}, 1982)$ with strong radiation, this makes eastern China one of the most unique regions in the world for studying the impact of mixed BB and FF pollution on the environment, weather and even regional climate.

This study further highlights the significant role of comprehensive measurements based on "flagship" station suggested by Hari et al. (2009), and also suggests a way forward of cross-disciplinary efforts, including meteorology and atmospheric chemistry and physics utilizing both observations and modeling, in improving the understanding of the earth 


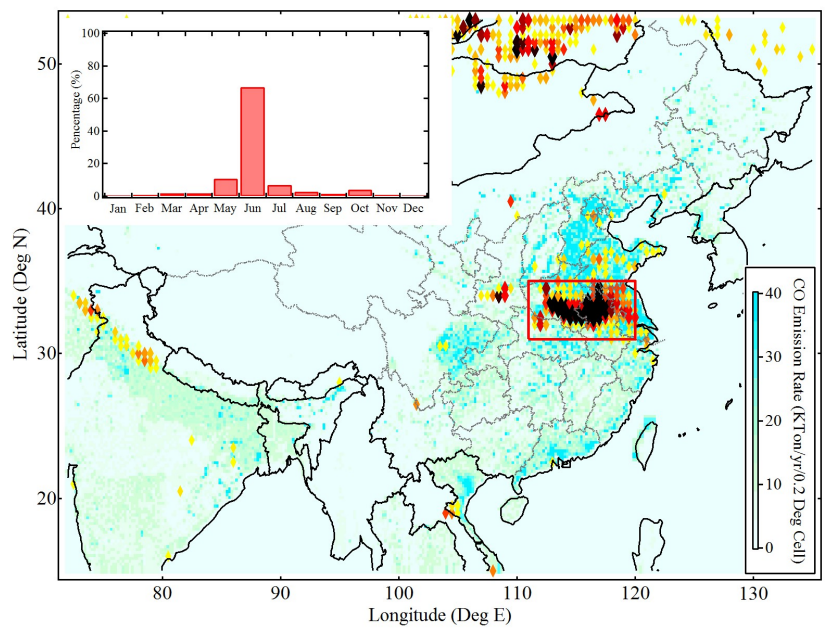

Fig. 10. A map showing anthropogenic emission inventory of $\mathrm{CO}$ (Zhang et al., 2009) and averaged active fire data during 2002-2012 over Asia based on MODIS Collection 5 Active Fire Product. The upper left corner shows seasonal variation of month percentage of active fires during the $11 \mathrm{yr}$. Note: the color (from yellow to black) and size of rhombuses represent the intensive of fires per grid.

system processes and their interactions in this monsoon region with intensive human activities.

Acknowledgements. This work was funded by the MOST 973 Program (2010CB428500 and 2010CB950700), National Natural Science Foundation of China (D0510/41275129) and the Jiangsu Provincial 2011 Program (Collaborative Innovation Center of Climate Change). The SORPES-NJU stations were supported by the ' 985 Program and the Fundamental Research Funds for Central Universities from Ministry of Education, China. Part of the activities were also supported by the Academy of Finland projects $(1118615,139656)$ and the European Commission via ERC Advanced Grant ATM-NUCLE. We appreciate iLEAPS SSC for brainstorming discussions on the Interdisciplinary Biomass Burning Initiative (IBBI). We acknowledge P. Hari from University of Helsinki (UH) for his advice on the development of SORPESNJU, and Pasi Aalto of UH for technical support of the DMPS instrument and data analysis. We thank W. X. Wang's team at Shandong University for their support on the field study. We also thank Metrohm Co. China for providing the MARGA analyzer and Z. Yan and J. Gao for their technical support for the instrument.

Edited by: S. M. Noe

\section{References}

Aalto, P., Hämeri, K., Becker, E., Weber, R., Salm, J., Mäkelä, J. M., Hoell, C., O'dowd, C. D., Hansson, H.-C., Väkevä, M., Koponen, I. K., Buzorius, G., and Kulmala, M.: Physical characterization of aerosol particles during nucleation events, Tellus B, 53, 344358, 2001.

Alvarado, M. J. and Prinn, R. G.: Formation of ozone and growth of aerosols in young smoke plumes from biomass burning: 1. Lagrangian parcel studies, J. Geophys. Res., 114, D09306, doi:10.1029/2008JD011144, 2009.

Andreae, M. O., Rosenfeld, D., Artaxo, P., Costa, A. A., Franck, G. P., Longo, K. M., and Silva-Dias, M. A. F.: Smoking rain clouds over the Amazon. Science, 303, 1338-1342, doi:10.1126/science.1092779, 2004.

Byun, D, and Schere, K. L.: Review of the governing equations, computational algorithms, and other components of the models3 Community Multiscale Air Quality (CMAQ) modeling system, Appl. Mech. Rev., 59, 51-77, doi:10.1115/1.2128636, 2006.

Carmona, I., Kaufman, Y. J., and Alpert, P: Using numerical weather prediction errors to estimate aerosol heating, Tellus, 608, 729-741, 2008.

Chan, C. K. and Yao, X. H.: Air pollution in Mega cities in China a review, Atmos. Environ., 42, 1-42, 2008.

Ding, A. J., Wang, T., Thouret, V., Cammas, J.-P., and Nédélec, P.: Tropospheric ozone climatology over Beijing: analysis of aircraft data from the MOZAIC program, Atmos. Chem. Phys., 8, 1-13, doi:10.5194/acp-8-1-2008, 2008.

Ding, A. J., Wang, T., Xue, L. K., Gao, J., Stohl, A., Lei, H. C., Jin, D. Z., Ren, Y., Wang, Z. F., Wei, X. L., Qi, Y. B., Liu, J., and Zhang, X. Q.: Transport of north China midlatitude cyclones: Case study of aircraft measurements in summer 2007, J. Geophys. Res., 114, D08304, doi:10.1029/2008JD011023, 2009.

Ding, A. J., Fu, C. B., Yang, X. Q., Sun, J. N., Zheng, L. F., Xie, Y. N., Herrmann, E., Nie, W., Petäjä, T., Kerminen, V.-M., and Kulmala, M.: Ozone and fine particle in the western Yangtze River Delta: an overview of $1 \mathrm{yr}$ data at the SORPES station, Atmos. Chem. Phys., 13, 5813-5830, doi:10.5194/acp-13-58132013, 2013.

Du, H., Kong, L., Chen, T., Cheng, J., Yang, X., Zhang, R., Han, Z., Yan, Z., and Ma, Y.: Insights into ammonium particleto-gas conversion: non-sulfate ammonium coupling with nitrate and chloride, Aerosol Air Qual. Res., 10, 589-595, doi:10.4209/aaqr.2010.04.0034, 2010.

Fan, J. W., Leung, L. R., Li, Z. Q., Morrison, H., Chen, H. B., Zhou, Y. Q., Qian, Y., and Wang, Y.: Aerosol impacts on cloud and preciptation in eastern China: Results from bin and bulk microphysics, J. Geophys. Res., 117, D00K36, doi:10.1029/2011JD016537, 2012.

Feingold, G., Jiang, H. L., and Harrington, J. Y.: On smoke suppression of clouds in Amazonia, Geophys. Res. Lett., 32, L02804, doi:10.1029/2004GL021369, 2005.

$\mathrm{Fu}, \mathrm{C}$. B.: A possible relationship between pulsation of plum rains in Chang-Jiang valley and snow and ice cover on Antarctica and the Southern Ocean, Chinese Sci. Bull., 27, 71-71, 1982.

Giglio, L., Csiszar, I., and Justice, C. O.: Global distribution and seasonality of active fires as observed with the Terra and Aqua MODIS sensors, J. Geophys. Res., 111, G02016, doi:10.1029/2005JG000142, 2006. 
Giorgi, G., Bi, X. Q., and Qian, Y.: Indirect vs. direct effects of anthropogenic sulfate on the climate of East Asia as simulated with a regional coupled climate chemistry/aerosol model, Clim. Change, 58, 345-376, 2003.

Gong, D. Y., Ho, C. H., Chen, D. L., Qian, Y., Choi, Y. S., and Kim, J. W.: Weekly cycle of aerosol-meteorology interaction over China, J. Geophys. Res., 112, D22202, doi:10.1029/2007JD008888, 2007.

Grell, G., Peckham, S. E., Schmitz, R., McKeen, S. A., Frost, G., Skamarock, W. C., and Eder, B.: Fully coupled "online" chemistry with the WRF model, Atmos. Environ., 39, 6957-6975, 2005.

Grell, G., Freitas, S. R., Stuefer, M., and Fast, J.: Inclusion of biomass burning in WRF-Chem: impact of wildfires on weather forecasts, Atmos. Chem. Phys., 11, 5289-5303, doi:10.5194/acp11-5289-2011, 2011.

Hari, P., Andreae, M. O., Kabat, P., and Kulmala, M: A comprehensive network of measuring stations to monitor climate change, Boreal. Eviron. Res., 14, 442-446, 2009.

He, K. B., Huo, H., and Zhang, Q.: Urban air pollution in China: Current status, characterizes and progress, Annu. Rev. Energ. Env., 27, 397-431, doi:10.1146/annurev.energy.27.122001.083421, 2002.

Hegarty, J., Mao, H., and Talbot, R.: Synoptic controls on summertime surface ozone in the northeastern United States, J. Geophys. Res., 112, D14306, doi:10.1029/2006JD008170, 2007.

Herrmann, E., Ding, A. J., Kerminen, V.-M., Petäjä, T., Yang, X. Q., Sun, J. N., Qi, X. M., Manninen, H., Hakala, J., Nieminen, T., Aalto, P. P., Kulmala, M., and Fu, C. B.: Aerosols and nucleation in Eastern China: first insights from the new SORPES-Station, Atmos. Chem. Phys. Discuss., 13, 2233722381, doi:10.5194/acpd-13-22337-2013, 2013.

Jacobson, M. Z.: GATOR-GCMM: A global-through urban-scale air pollution and weather forecast model 1 . Model design and treetment of subgrid soil, vegetation, roads, rooftops, water, sea ice and snow, J. Geophys. Res., 106, 5385-5401, 2001a.

Jacobson, M. Z.: Strong radiative heating due to the mixing state of black carbon in atmospheric aerosols, Nature, 409, 695-697, $2001 b$.

Kulmala, M., Maso, M. D., Makela, J. M, Pirjola, L., Vakeva, M., Aalto, P., Miikkulainen, P., Hameri, K., and O'Dowd, C. D.: On the formation, growth and composition of nucleation mode particles, Tellus B, 53, 479-490, 2001.

Li, J., Posfai, M., Hobbs, P. V., and Buseck, P. R.: Individual aerosol particles from biomass burning in southern Africa: 2. Composition and aging of inorganic particles, J. Geophys. Res., 108, 8484, doi:10.1029/2002JD002310, 2003.

Li, Z., Niu, F., Fan, J. W., Liu, Y. G., Rosenfeld, D., and Ding Y. N.: Long-term impacts of aerosols on the vertical development of clouds and precipitation, Nat. Geosci., 4, 888-894, 2011a.

Li, Z., Li, C., Chen, H., Tsay, S.-C., Holben, B., Huang, J., Li, B., Maring, H., Qian, Y., Shi, G., Xia, X., Yin, Y., Zheng,Y., and Zhuang, G.: East Asian studies of tropospheric aerosols and their impact on regional climate (EAST-AIRC): An overview, J. Geophys. Res., 116, D00K34, doi:10.1029/2010JD015257, $2011 \mathrm{~b}$.

Liu, G., Sun, J. N., and Jiang, W. M. Observational verification of urban surface roughness parameters derived from morphological models, Meteorol. Appl., 16, 205-213, 2009.
Liu, P. F., Zhao, C. S., Göbel, T., Hallbauer, E., Nowak, A., Ran, L., Xu, W. Y., Deng, Z. Z., Ma, N., Mildenberger, K., Henning, S., Stratmann, F., and Wiedensohler, A.: Hygroscopic properties of aerosol particles at high relative humidity and their diurnal variations in the North China Plain, Atmos. Chem. Phys., 11, 3479-3494, doi:10.5194/acp-11-3479-2011, 2011.

Liu, Y., Bourgeois, A., Warner, T., Swerdlin, S., and Hacker, J.: An implementation of obs-nudging-based FDDA into WRF for supporting ATEC test operations, 2005 WRF user workshop, Paper 10.7, 2005.

Malm, W. C. and Day, D. E.: Estimates of aerosol species scattering characteristics as a function of relative humidity, Atmos. Environ., 35, 2845-2860, 2001.

Otte, T. L., Pouliot, G., Pleim, J. E., Young, J. O., Schere, K. L., Wong, D. C., Lee, P. C. S., Tsidulko, M., McQueen, J. T., Davidson, P., Mathur, R., Chung, H. Y., DiMego, G., and Seaman, N. L.: Linking the Eta Model with the Community Multiscale Air Quality (CMAQ) Modeling System to build a National Air Quality Forecasting System, Weather Forecast., 20, 367-384, 2005.

Qian, Y., Gong, D. Y., Fan, J. W., Leung, L. R., Bennartz, R., Chen, D. L., and Wang, W. G.: Heavy pollution suppresses light rain in China: Observations and modeling, J. Geophys. Res., 114, D00K02, doi:10.1029/2008JD011575, 2009.

Ramanathan, V., Li, F., Ramana, M. V., Praveen, P. S., Kim, D., Corrigan, C. E., Nguyen, H., Stone, E. A., Schauer, J. J., Carmichael, G. R., Adhikary, B., and Yoon, S. C.: Atmospheric brown clouds: Hemispherical and regional variations in long-range transport, abosption, and radiative forcing, J. Geophys. Res., 112, D22S21, doi:10.1029/2006JD008124, 2007.

Richter, A., Burrows, J. P., Nub, H., Granier, C., and Niemeier, C.: Increase in tropospheric nitrogen dioxide over China observed from space, Nature, 437, 129-132, doi:10.1038/nature04092, 2005.

Robock, A.: Surface cooling due to forest fire smoke, J. Geophys. Res., 96, 20869-20878, 1991.

Rosenfeld, D., Lohmann, U., Raga, G. B., O’Dowd, C. D., Kulmala, M., Fuzzi, S., Reissell, A., and Andreae, M. O.: Flood or drought: how do aerosols affect precipitation?, Science, 321, 1309-1313, 2008.

Skamarock, W. C., Klemp, J. B., Dudhia, J., Gill, D. O., Barker, D. M., Wang, W., and Powers, J. G.: A Description of the Advanced Research WRF Version 2, Natl. Cent. for Atmos. Res., Boulder, CO, USA, 2005.

Tie, X. X. and Cao, J. J.: Aerosol pollution in China: Present and future impact on environment, Particuology, 7, 426-431, 2009.

Wang, M. H., Ghan, S., Liu, X. H., L'Ecuyer, T. S., Zhang, K., Morrison, H., Ovchinnikov, M., Easter, R., Marchand, R., Chand, D., Qian, Y., and Penner, J. E.: Constraining cloud lifetime effects of aerosols using A-Train satellite observations, Geophys. Res., Lett., 39, L15709, doi:10.1029/2012GL052204, 2012.

Wang, T., Wong, C. H., Cheung, T. F., Blake, D. R., Arimoto, R., Baumann, K., Tang, J., Ding, G. A., Yu, X. M., Li, Y. S., Streets, D. G., and Simpson I. J.: Relationships of trace gases and aerosols and the emission characteristics at Lin'an, a rural site in eastern China, during spring 2001, J. Geophys. Res., 109, D19S05, doi:10.1029/2003JD004119, 2004.

Wexler, H.: The great smoke pall - 24-30 September 1950, Weatherwise 3, 129-142, 1950. 
Xu, X., Lin, W., Wang, T., Yan, P., Tang, J., Meng, Z., and Wang, Y.: Long-term trend of surface ozone at a regional background station in eastern China 1991-2006: enhanced variability, Atmos. Chem. Phys., 8, 2595-2607, doi:10.5194/acp-8-2595-2008, 2008.

Yuan, B., Liu Y., Shao, M., Lu, S. H., and Streets, D.: Biomass burning contributions to ambient VOCs species at a receptor site in the Pearl River Delta (PRD), China, Environ. Sci. Technol., 44, 4577-4582, 2010.

Zhou, Y., Wang, T., Gao, X. M., Xue, L. K., Wang, X. F., Wang, Z., Gao, J., Zhang, Q. Z., and Wang, W. X.: Continuous observations of water soluble ions in $\mathrm{PM}_{2.5}$ at Mount Tai (1534 m a.s.1.) in central-eastern China, J. Atmos. Chem., 64, 107-127, 2009.

Zhang, H., Hu, D., Chen, J., Ye, X. N. Wang, S. X., Hao, J. M., Wang, L., Zhang, R. Y., and An, Z. S.: Particle size distribution and polycyclic aromatic hydrocarbons emissions from agriculture crop residue burning, Environ. Sci. Tech., 45, 5477-5482, 2011.

Zhang, M., Chen, J. M., Chen, X. Y., Cheng, T. T., Zhang, Y. L., Zhang, H. F., Ding, A. J., Wang, M., and Mellouki, A.: Urban aerosol characteristics during the World Expo 2010 in Shanghai, Aerosol Air Qual. Res., 13, 36-48, doi:10.4209/aaqr.2012.02.0024, 2013.
Zhang, Q., Streets, D. G., Carmichael, G. R., He, K. B., Huo, H., Kannari, A., Klimont, Z., Park, I. S., Reddy, S., Fu, J. S., Chen, D., Duan, L., Lei, Y., Wang, L. T., and Yao, Z. L.: Asian emissions in 2006 for the NASA INTEX-B mission, Atmos. Chem. Phys., 9, 5131-5153, doi:10.5194/acp-9-5131-2009, 2009.

Zhang, R. J., Xu, Y. F., and Han, Z. W.: Inorganic chemical composition and source signature of PM2.5 in Beijing during ACE-Asia period, Chinese Sci. Bull., 48, 1002-1005, 2003.

Zhang, R. Y., Li, G. H., Fan, J. W., Wu, D. L., and Molina, M. J.: Intensification of Pacific storm track linked to Asian pollution, $\mathrm{P}$. Natl. Acad. Sci. USA, 104, 5295-5299, 2007.

Zhang, Y., Mao, H. T., Ding, A. J., Zhou, D. R., and Fu, C. B.: Impact of synoptic weather patterns on spatio-temporal variation in surface $\mathrm{O}_{3}$ levels in Hong Kong during 1999-2011, Atmos. Environ., 73, 41-50, 2013. 